\title{
Pratiques
}

Linguistique, littérature, didactique

179-180 | 2018

Poésie et langue : aspects théoriques et didactiques

\section{Questions aux poètes}

Questions to poets

\section{Michel Favriaud}

\section{(2) OpenEdition \\ Journals}

Édition électronique

URL : http://journals.openedition.org/pratiques/4642

DOI : $10.4000 /$ pratiques.4642

ISSN : 2425-2042

\section{Éditeur}

Centre de recherche sur les médiations (CREM)

\section{Référence électronique}

Michel Favriaud, «Questions aux poètes », Pratiques [En ligne], 179-180 | 2018, mis en ligne le 31 décembre 2018, consulté le 01 mai 2019. URL : http://journals.openedition.org/pratiques/4642 ; DOI : $10.4000 /$ pratiques.4642

Ce document a été généré automatiquement le 1 mai 2019.

(c) Tous droits réservés 


\title{
Questions aux poètes
}

\author{
Questions to poets
}

\section{Michel Favriaud}

1 1. Dans ce numéro de la revue Pratiques consacrée à la poésie, au rapport de la poésie à la langue d'un côté et à la didactique de l'autre, j'ai souhaité interroger, à côté ou en vis-àvis de linguistes, des poètes, mais uniquement des poétesses. Comment avez-vous réagi? Comment vivez-vous en poésie, et de quelle sorte de poésie vivez-vous?

2 2. La poésie joue la langue. Le poète crée sa langue dans la langue de tous, sa langue avec sa syntaxe, sa ponctuation... Quel est votre rapport avec la langue dans l'écriture ? Faut-il être syntacticien comme le pensait S. Mallarmé, en quête d'une "garantie " suprême, pour être poète ? La langue se travaille-t-elle à l'oreille, à la vue, à... l'éthique... ou dans une démarche réflexive? Attendez-vous du lecteur qu'il soit attentif à votre langue? Faites-vous, en écrivant, une expérience de langue, de réflexion sur la langue avec lui ?

3 3. La poésie est-elle pour vous une exploration du monde, et même une expérimentation? On a l'impression que pour P. Jaccottet, A. du Bouchet, L. Gaspar... la poésie non seulement part d'une expérience du monde mais la recrée, l'amplifie, la clarifie dans le laboratoire de l'écriture ? Y a-t-il d'autres formes d'expérimentation du monde et de soi qui vous conduisent?

4 4. Dans la littérature, et la poésie particulièrement, la question de l'« imaginaire » semble brûlante : Y. Bonnefoy, P. Chamoiseau, F. Cheng, P. Quignard et A. Herbauts, l'auteureillustratrice de littérature de jeunesse, entre autres, s'y sont coltinés en France ces dix dernières années, les quatre premiers comme dans un testament d'écriture. Cette question pourrait être capitale pour les jeunes à l'école, notamment les jeunes en difficulté scolaire, ceux dont l'imaginaire n'arrive pas à sympathiser avec cette institution. Comment, vous, définiriez-vous cette notion complexe, quasi insaisissable? Votre écriture rencontre-t-elle cette question de la quête ou de la reconquête de l'imaginaire?

5 5. La poésie existe aussi par la voix, intérieure ou extérieure, peut-être par le dialogue des voix. Lisez-vous des poèmes en public? Qu'est-ce que vous attendez d'une lecture 
publique de vos œuvres ou de celle de poètes aimés? Quel rapport s'établit alors avec le public, avec vos lecteurs?

6 6. Pouvez-vous nous parler d'un de vos plus beaux projets " quasi-didactiques », si vous en faites, avec des élèves, du primaire, du secondaire, du supérieur, ou avec d'autres populations ? Qu'est-ce que ça vous apporte et qu'est-ce que ça leur apporte? Aux enfants en difficulté, aux personnes plus ou moins en marge de la société ? Quel autre usage de la poésie à l'école permettrait de mieux « éduquer » les jeunes, les « gens »?

\section{RÉSUMÉS}

$\mathrm{Au}$ questionnaire proposé à six poètes, en miroir de celui des linguistes, ont répondu : Édith Azam, Françoise Delorme, Danièle Faugeras, Irène Gayraud, Liliane Giraudon, Marie de Quatrebarbes. Chacune aura sélectionné en fin d'entretien deux titres de son œuvre et un ou deux de ses contemporains qui ont retenu son attention; parmi les vingt titres retenus, juste un auteur est cité deux fois. L'une est aussi éditrice, deux sont traductrices, deux pratiquent un autre art, une un artisanat, et presque toutes ont l'habitude de dire leurs poèmes à l'école primaire ou secondaire et de conduire des ateliers d'écriture. Voici les problématiques abordées : 1) Leur réaction à l'échantillon uniquement féminin de l'enquête et au terme de "poétesse »;2) leur relation à la langue et à la syntaxe ; 3) l'exploration et l'expérimentation du monde et de la vie par la poésie; 4) l'imaginaire: sa définition problématique, son rôle dans l'écriture et l'apprentissage ; 5) la relation de la poésie à la voix : voix interne(s) et externe(s) ; 6) Poésie, éducation, élèves en difficulté et interventions des poètes à l'école. La plupart des poètes-femmes refusent le terme de poétesse comme discriminatoire, suggérant une prétendue différence entre poésie masculine et féminine. L'échantillon féminin a fait généralement problème. Toutes disent que la langue est une composante fondamentale de l'écriture et de la lecture sans partager la même définition de la syntaxe : syntaxe normative ou système ouvert de la syntaxe étendue, ni la même conduite envers normes et règles. La plupart relèvent le rôle de la matière sonore et visuelle des mots, sans oser l'intégrer à la syntaxe étendue. La langue est retenue comme vie, mouvement corporel, désir, mais aussi comme échec, essai perpétuel, parfois comme maladie ou désastre. Le point de vue des poètes sur la langue est moins linguistique qu'existentiel et philosophique. Deux camps s'opposent pour savoir qui, de la langue ou du monde/de l'observation/de la perception/du ressenti, est le premier. Certains distinguent «réel» et « réalité, i.e, la réalité commune, superficielle: leur objectif serait d'affronter le réel en se débarrassant de la subjectivité et $\mathrm{du}$ « moi ». Mais la cible est régulièrement manquée. Le monde et la vie d'un côté, la langue de l'autre restent deux mystères durs à raccorder, quoique indissociables. L'imaginaire se définit différemment selon la culture de chacune; certaines se réfèrent à la psychanalyse et à Lacan, d'autres acceptent la distinction proposée entre imaginaire singulier et imaginaire collectif, certaines partent de l'acception adjectivale de monde imaginaire construit par chacun en propre. Juste une considère que le problème ne se pose pas pour un adulte, quand la plupart s'interrogent beaucoup, passionnément. L'imaginaire serait à la fois relié à la peur, aux peurs ancestrales et à leur revers: énergie, courage, pulsion créative, intersubjectivité, voire réflexivité. L'imaginaire, à la jointure entre inconscient, première levée d'images et de mots, alimenterait le désir de renaître toujours dans la langue et de dévoiler ou d'intensifier le réel. La diction publique est une pratique ordinaire que les poètes aiment et 
redoutent ; le corps est impliqué dans sa quasi-nudité, ce qui nécessite de la confiance mutuelle. Certaines y voient un champ d'expérimentation ou une étape de création. Dire la poésie, même silencieusement, est aussi une aide fréquente à l'écriture. Presque toutes font des récitals ou des ateliers (d'écriture ou de traduction de poèmes) dans les écoles ou dans d'autres lieux sociaux, ce qui accroît le rôle social de la poésie. Chacune parle des événements qui ont déclenché la réaction positive de tels élèves, en difficulté notamment. En tireraient profit d'abord l'image de soi et la motivation en lien avec la vie intérieure; ensuite le goût d'apprendre, de vivre, de regarder, quelle que soit la discipline; enfin l'attention plus fine à la langue, à son fonctionnement et à sa sémiose. Mais toutes insistent sur l'«écopoésie » en tant que milieu d'apprentissage et de rencontres humaines, l'année durant, plutôt que sur des projets didactiques ciblés sur une seule matière, langue maternelle ou étrangère. Donc, même si les réponses des poètes et des linguistes s'accordent largement sur la langue, la voix et l'enseignement, elles divergent néanmoins sur la définition de la poésie, là plus centrée sur le fonctionnement de la langue, ici branchée sur le corps, l'imaginaire, le réel. Mais on découvre entre eux une fascination réciproque, comme si les uns avaient un pouvoir mystérieux dont les autres seraient privés.

The questionnaire proposed to six poets, echoing the one for linguists, is filled up by: Edith Azam, Françoise Delorme, Danièle Faugeras, Irène Gayraud, Liliane Giraudon, Marie de Quatrebarbes. Each of them has selected, at the end of the interview, two titles of her own works and one or two contemporaries from her recent reading who deserve to be known. Among these 20 books, only one author is referred twice. One of the poets is moreover an editor, two are translators, and two practice another art, one handicraft. Almost all of them are used to perform their poems in primary or secondary schools and some of them lead creative writing workshops. Here are the issues raised by the questionnaire: 1) Their reaction towards the "women-only" sampling in the questionnaire and their attitudes towards the word "poetess"; 2) their relation with language and syntax; 3) The exploration and experimentation of world and life through poetry ; 4) imaginary (as a noun): its problematic definition, its role in writing and learning; 5) the relation between poetry and voice: internal and external voice(s); 6) poetry, education, non-enhanced students and poets' interventions in schools. Most of the poets do not accept the word 'poetess', regarding it as a discrimination, which suggests the so-called difference between masculine and feminine poetry. The "women-only" sampling becomes therefore a problem. Language is widely accepted as a fundamental component in writing and reading but people share distinguished definitions of syntax including the standard syntax, the extended syntax as an open system, or the same behavior towards norms and rules. A majority emphasizes the role of sound /visual materials in words, but dare not to admit their places in extended syntax. Language is considered as life, physical movement, desire but also as failure, perpetual attempt, sometimes as disaster or disease. The poets' point of view of language is less linguistic, more existential and philosophical. Two camps stand against each other on the question whether language or the world/the observation/the perception/the feeling, comes the first? Some of them make the difference between 'real" and 'reality', i.e. common and superficial reality: their target would be to face the real, sometimes by getting rid of their own subjectivity and themselves. But the target is regularly missed. The world and life on one side, and language on the other side, stand as two mysteries hard to connect, however inseparable. Imaginary is defined differently along with the culture. Some refer to the psychoanalysis or Lacan, some accept the proposed distinction between singular imaginary and collective imaginary, others take it as an adjective of the imaginary world built by each person. Just one does not consider it as an issue for adults, whereas most of them discuss this issue with passion. Imaginary would connect the fear, the ancestoral fear and their failures: energy, courage, creative impulse, intersubjectivity, and even reflexivity. Imaginary, at the crossroad of unconscious, together with the first rise of images and words, would feed the desire to revive again and again through language and to unveil or 
intensify the real. Saying poetry aloud in public is a common practice poets generally like and fear. Body is involved, almost naked, which therefore needs mutual confidence. For some, it is an experimentation area or a step of creation. Saying poetry, even just in silence, is also a frequent help to writing. Almost all the poets manage performances and workshops (writing or translating poems) in schools or in other social places, therefore strengthening the social role of poetry. Everyone says about positive reactions in some pupils triggered by poetry, especially in the nonenhanced ones. The first benefit would be a better self-image and motivation in connection with inner life; the second is the appetites to learn, to live and to look, whatever the discipline is; and thirdly, it brings an accurate attention towards the language, its functioning and the semiosis. But all insist on 'écopoésie', i.e learning environment all along the year, and the human meetings rather than strict teaching projects devoted to one topic only, mother tongue or foreign language. So, even if the responses from the poets and linguists demonstrate their wide agreements on language, voice and teaching, they, nevertheless, differ a lot on their definition of poetry: linguists concentrate on the language functioning while poets focus more on body, imaginary and 'real'. But there exists a kind of mutual charm flowing between them, as if each side held the mysterious power that the other side had been deprived of.

\section{INDEX}

Mots-clés : poésie, syntaxe, imaginaire, voix, matière sonore, motivation des élèves, écriture créative

Keywords : poetry, syntax, imaginary, voice, sound material, student motivation, creative writing

\section{AUTEUR}

\section{MICHEL FAVRIAUD}

Université Toulouse - Jean Jaurès, LLA-Créatis, EA 4152, F-31000, France 